\title{
Anal Myolipoma: A New Benign Entity in Patients with an Anal Tumor?
}

\author{
Tae Young Kang, Moo Ryang Huh, Su Jin Kim ${ }^{1}$ \\ Sarang Surgical Clinic, Busan; ${ }^{1}$ Department of Pathology, Donga-A University College of Medicine, Busan, Korea
}

A myolipoma is an extremely rare benign neoplasm, occurring most frequently in adults in the deep soft tissue of the abdomen or retroperitoneum. We experienced a case of an anal myolipoma occurring in a 30-year-old woman, and it was surgically resected. To our knowledge, this is the first reported case of a myolipoma arising from the anus, so such a possibility needs to be considered in the differential diagnosis.

Keywords: Myolipoma; Angiomyolipoma; Anus

\section{INTRODUCTION}

Among several lipomatous tumor variants, a myolipoma is a very rare benign lesion composed of mature adipocyte and benign smooth muscle fibers. Although the pathogenesis of a myolipoma remains unclear, there are two main theories that explain the mechanism: namely, adipose metaplasia and a multipotential Müllerian cell origin [1]. A myolipoma is mostly found incidentally in the deep soft tissue of the abdomen or retroperitoneum. However, there have been very few cases in which the tumor has affected other anatomical sites. Because all the surgically-treated myolipomas that have been reported have been benign regardless of their location, normally a complete surgical excision is performed for the treatment of these lesions. To date, no case of an anal myolipoma has been reported in the English literature. In this report, we present the first case of a surgically-resected myolipoma on the anal margin.

Received: October 12,2011 • Accepted: December 5, 2011

Correspondence to: Tae Young Kang, M.D.

Sarang Surgical Clinic, 535 Suyeong-ro, Suyeong-gu, Busan 613-806, Korea Tel: +82-51-756-4488, Fax: +82-51-756-0419

E-mail:1300007@daum.net

(C) 2012 The Korean Society of Coloproctology

This is an open-access article distributed under the terms of the Creative Commons Attribution NonCommercial License (http://creativecommons.org/licenses/by-nc/3.0) which permits unrestricted noncommercial use, distribution, and reproduction in any medium, provided the original work is properly cited.

\section{CASE REPORT}

A 30-year-old female presented with a progressively growing perianal mass. The mass had been slowly increasing in size for 17 years. Physical examination showed a $6 \times 4 \times 4 \mathrm{~cm}^{3}$, firm, ovoid mass with a wide pedicle extending to the anal margin at 2 to 10 o'clock (Fig. 1). The mass was apart from the vagina and had a somewhat firm and cord-like lesion within a pedicle. She also had grade II to III internal hemorrhoids at 3 and 7 o'clock. Nothing remarkable was noted in the laboratory work-ups, including complete blood cell count, blood chemistry, urinalysis, and plain chest radiograph. A wide surgical excision was performed. A cord-like lesion arising in the intersphincteric groove was the root of vessels and was treated by suture ligation (Fig. 2). Concurrently, her hemorrhoids were treated by ligation and excision.

Macroscopically, the tumor was well-encapsulated, and the consistency was a little firm.

The cut surface contained gray-white or yellowish areas (Fig. 3). Microscopically, the tumor was composed of mature adipose tissue and smooth muscle fibers. They were intermingled with each other irregularly. Abundant dilated and thin-walled blood vessels were observed, but neither mitosis nor cellular atypia was shown (Fig. 4). Immunohistochemically, the smooth muscle fibers and blood vessel walls were positive for smooth muscle actin, but negative for CD34, c-kit and HMG-45 (Fig. 5).

The patient recovered without any postoperative complications. We carried out follow-ups regularly for 6 months, and she showed no evidence of recurrence. 


\section{Coloproctology Tae Young Kang, et al.}

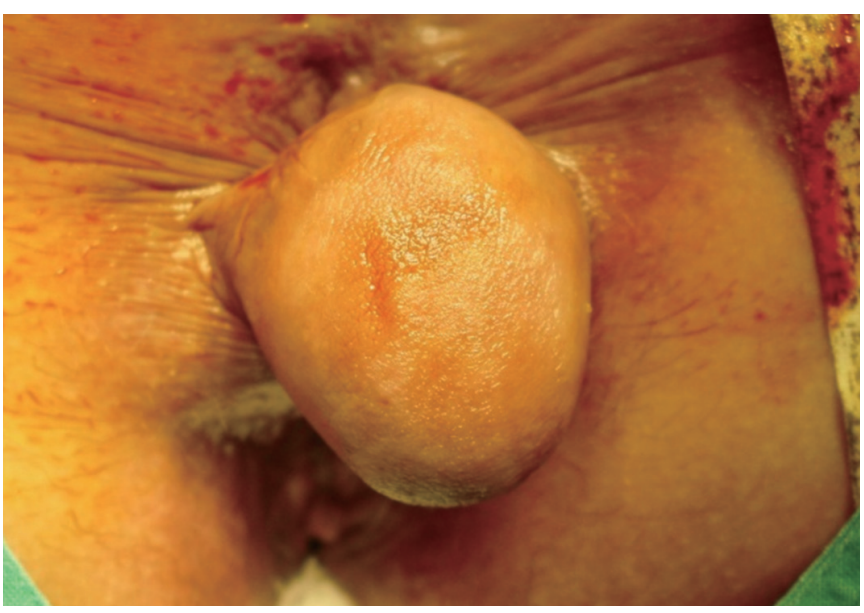

Fig. 1. Anal mass in a patient in the jack-knife position. A $6 \times 4 \times 4$ $\mathrm{cm}^{3}$, firm, ovoid mass has a wide pedicle extending from 2 to 10 o'clock on the anal margin.

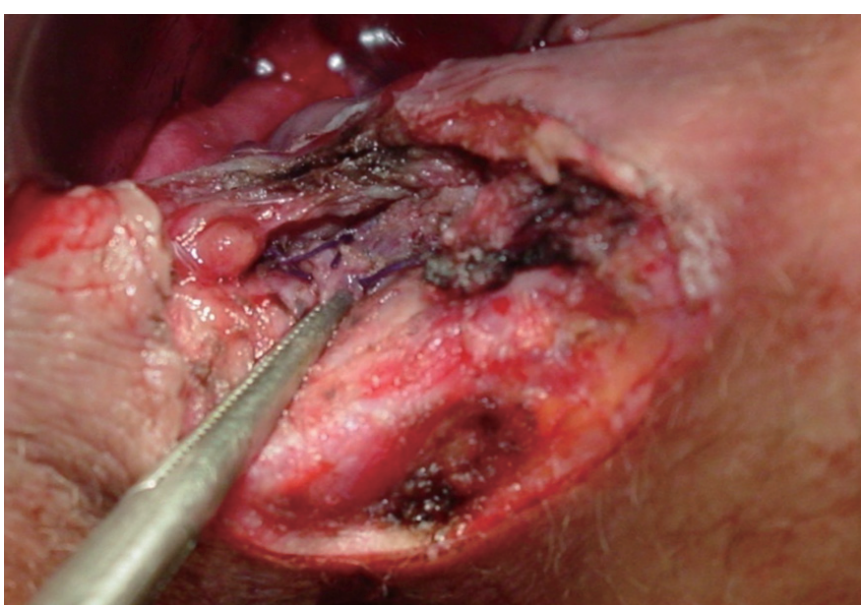

Fig. 2. Root of vessels seen as a cord-like lesion at the intersphincteric groove, which was treated using suture ligation.

\section{DISCUSSION}

In the literature, benign tumors of the anal margin may range from innocuous in situ Bowen's disease to clinically aggressive verrucous lesions [2]. However, no obvious statistical data for benign tumors arising from the anal margin are available. According to the World Health Organization's classification of soft tissue tumors in 2002, benign lipomatous lesions are classified into nine categories: lipoma, lipomatosis, lipomatosis of nerves, lipoblastoma/lipoblastomatosis, angiolipoma, myolipoma, chondroid lipoma, spindle cell/pleomorphic lipoma, and hibernoma [3]. Among these lipomatous lesions, a myolipoma of soft tissue is a very rare benign lipomatous lesion [4].

In 1991, the first nine cases of a soft tissue myolipoma were described by Meis and Enzinger [5]. They reported nine cases of a

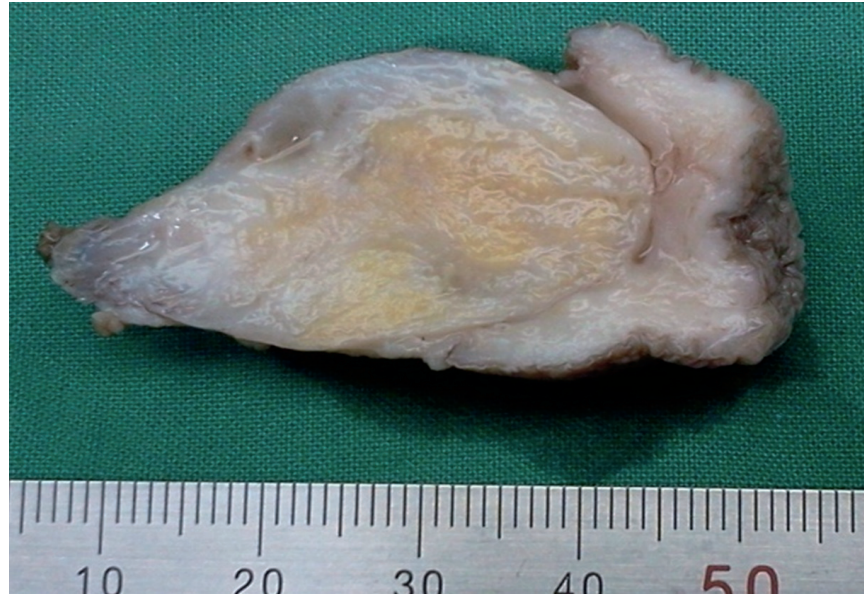

Fig. 3. Macroscopic appearance of a well-encapsulated tumor showing lobules of fatty tissue, as well as bands and nodules of firm white tissue.

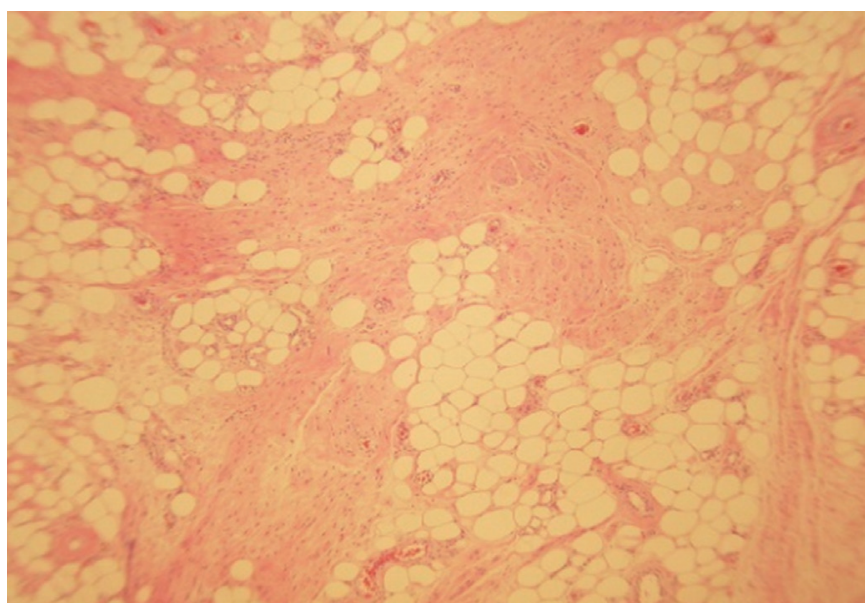

Fig. 4. The tumor is composed of mature adipose tissue intermingled with smooth muscle fibers and abundant blood vessels $(\mathrm{H} \& \mathrm{E}, \times 40)$.

previously undescribed benign soft tissue tumor: one in the subcutaneous adipose tissue, one in the rectus sheath of the anterior abdominal wall, two within the abdominal cavity attached to the abdominal wall, two in the inguinal region, and three in the retroperitoneum [5]. It has also been reported in various anatomical sites, including the spinal cord, orbit, round ligament, and breast [6-9]. Myolipoms occur most frequently in adults in their 5th and 6th decades of life, with a female predilection (2:1 ratio) [4]. Grossly, these tumors are usually completely, or at least partially, encapsulated and have a yellow to white appearance. A histological analysis demonstrates a variable admixture of smooth muscle and mature adult adipose tissue [4]. The smooth muscle component often predominates, with a typical ratio of 2:1 (muscle to fat) [10].

In our case, microscopic findings closely mimicked those of an angiomyolipoma (AML) because of abundant vessels. However, 


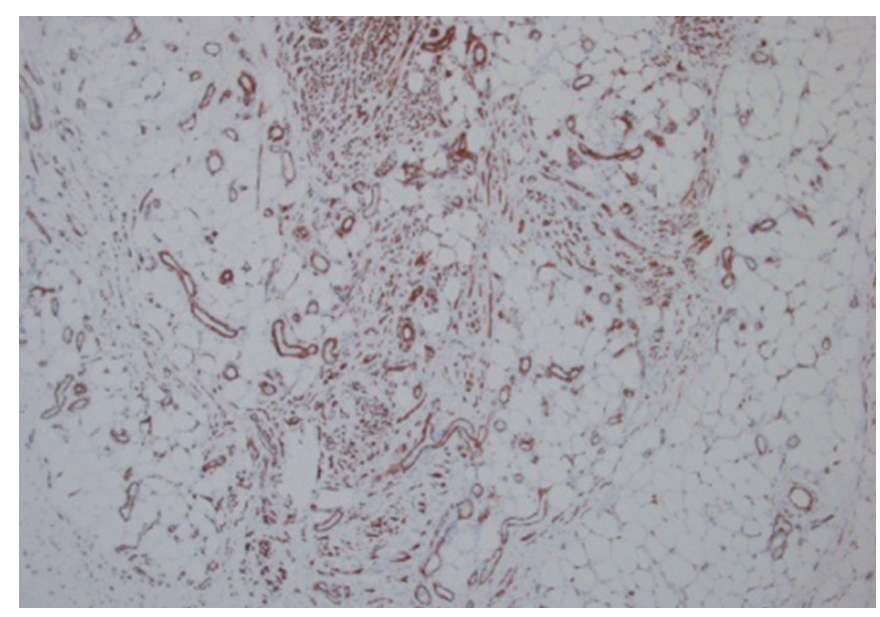

Fig. 5. Immunohistochemical staining for smooth muscle actin (SMA). The smooth muscle fibers and blood vessel walls are positive for SMA $(\times 40)$.

this tumor was immunohistochemically negative for HMB- 45 staining and contained no medium-sized arteries distinctive of an AML. AML is also a rare soft tissue tumor and probably a hamartomatous process, which is mostly found in the kidneys [11]. It is usually associated with tuberous sclerosis or is sporadic [12]. Furthermore, extrarenal AMLs are very rare tumors that have been reported in various organs, including the liver (second most common site), colon and skin $[11,13,14]$. Although the majority of AML cases follow a benign course, malignant transformation of an AML has also been reported [15]. In previously reported cases of a myolipoma, neither postoperative recurrence nor metastasis has been noted, and both the histological appearance and the clinical course suggest that it has a benign nature. Here, we conducted a careful follow-up survey to identify any long-term complications. In conclusion, we report a case of a myolipoma arising from the anus. Thus, consideration of a soft tissue myolipoma in the differential diagnosis of fat-containing lesions of the anus is important if an accurate diagnosis is to be made.

\section{CONFLICT OF INTEREST}

No potential conflict of interest relevant to this article was reported.

\section{REFERENCES}

1. Dellacha A, Di Marco A, Foglia G, Fulcheri E. Lipoleiomyoma of the uterus. Pathologica 1997;89:737-41.

2. Nelson H. Anus. In: Townsend CM, Beauchamp RD, Evers BM, Mattox KL, editors. Sabiston textbook of surgery: the biological basis of modern surgical practice. 17th ed. Philadelphia: Elsevier Saunders; 2004. p. 1483-512.

3. Christopher D, Unni K, Mertens F. Adipocytic tumors. In: Fletcher CD, Unni KK, Mertens F, editors. Pathology and genetics: tumors of soft tissue and bone. Lyon: IARC; 2002. p. 19-46. (World Health Organization classification of tumours; 4).

4. Murphey MD, Carroll JF, Flemming DJ, Pope TL, Gannon FH, Kransdorf MJ. From the archives of the AFIP: benign musculoskeletal lipomatous lesions. Radiographics 2004;24:1433-66.

5. Meis JM, Enzinger FM. Myolipoma of soft tissue. Am J Surg Pathol 1991;15:121-5.

6. Brown PG, Shaver EG. Myolipoma in a tethered cord. Case report and review of the literature. J Neurosurg 2000;92(2 Suppl): 214-6.

7. Nagayama A, Miyamura N, Lu Z, Tsuda Y, Kitaoka T, Amemiya T, et al. Light and electron microscopic findings in a patient with orbital myolipoma. Graefes Arch Clin Exp Ophthalmol 2003;241: 773-6.

8. Sonobe H, Ohtsuki Y, Iwata J, Furihata M, Ido E, Hamada I. Myolipoma of the round ligament: report of a case with a review of the English literature. Virchows Arch 1995;427:455-8.

9. McGregor DK, Whitman GJ, Middleton LP. Myolipoma of the breast: mammographic, sonographic, and pathologic correlation. Breast J 2004;10:259-60.

10. Weiss SW, Goldblum JR. Benign lipomatous tumors. In: Weiss SW, Goldblum JR, editors. Enzinger and Weiss's soft tissue tumors. 4th ed. St Louis: Mosby; 2001. p. 571-639.

11. Val-Bernal JF, Mira C. Cutaneous angiomyolipoma. J Cutan Pathol 1996;23:364-8.

12. Northrup H, Koenig MK, Au KS. Tuberous sclerosis complex. In: Pagon RA, Bird TD, Dolan CR, Stephens K, Adam MP, editors. GeneReviews $^{\mathrm{TM}}$ [Internet]. Seattle (WA): University of Washington, Seattle; 1993. [updated 2011 Nov 23; cited 2011 Aug 10]. Available from: http://www.ncbi.nlm.nih.gov/books/NBK1220/.

13. Hyams ES, Provet J. Angiomyolipoma of the left ureterovesical junction. Rev Urol 2007;9:84-8.

14. Maesawa C, Tamura G, Sawada H, Kamioki S, Nakajima Y, Satodate R. Angiomyolipoma arising in the colon. Am J Gastroenterol 1996;91:1852-4.

15. Nguyen TT, Gorman B, Shields D, Goodman Z. Malignant hepatic angiomyolipoma: report of a case and review of literature. Am J Surg Pathol 2008;32:793-8. 